\title{
The forgotten competitive arena: Strategy in natural resource industries
}

\begin{tabular}{|r|l|}
\hline Journal: & Academy of Management Perspectives \\
\hline Manuscript ID & AMP-2017-0158.R4 \\
\hline Document Type: & Article \\
\hline Keywords: & $\begin{array}{l}\text { Business-level strategy < Business and Competitive Strategy < Business } \\
\text { Policy and Strategy < Topic Areas, Business-level resources/capabilities } \\
\text { < Business and Competitive Strategy < Business Policy and Strategy }< \\
\text { Topic Areas, National competitiveness < Policy environment < } \\
\text { International Management < Topic Areas, Competitive dynamics }< \\
\text { Business and Competitive Strategy < Business Policy and Strategy }< \\
\text { Topic Areas, Industry structure analysis < Business and Competitive } \\
\text { Strategy < Business Policy and Strategy < Topic Areas }\end{array}$ \\
\hline
\end{tabular}




\title{
The Forgotten Competitive Arena: Strategy in Natural Resource Industries
}

\author{
Ariel A. Casarin \\ Universidad Adolfo Ibañez \\ ariel.casarin@uai.cl \\ Sergio G. Lazzarini \\ INSPER Institute of Education and Research \\ sergiog11@insper.edu.br
}

Roberto S. Vassolo*

IAE Business School of Argentina and Pontificia Universidad Católica de Chile rvassolo@iae.edu.ar

*Correspondence author

We acknowledge financial support from Núcleo Milenio Research Center in Entrepreneurial Strategy Under Uncertainty (NS130028), and Fondecyt (grant N1160048). The paper was greatly improved by the unstinting suggestions of two anonymous referees and the co-editor Dave Ketchen. 


\title{
The Forgotten Competitive Arena: Strategy in Natural Resource Industries
}

\begin{abstract}
Despite their importance in the global economy, the complex competitive dynamics of natural resource industries and their implications for business performance remain largely understudied in strategic management. This article identifies major traits that are highly relevant in natural resource industries, including the standardized nature of their products, their emphasis on process-based innovations, the presence of dual physical and financial derivative markets, and the importance of non-market forces that affect the creation and appropriation of rents from natural resources. We propose a general framework that guides our observations and, and we discuss research opportunities for the study of firm strategy in natural resource industries.
\end{abstract}

Keywords: natural resource industries, commodities, competitive dynamics, non-market strategy 
Natural resource industries are undoubtedly among the most important sectors of the world economy. Worldwide, at least 800 million people - about 25 percent of the total global workforce-work in agriculture or mining (Timmer, de Vries \& de Vries, 2015), producing commodities that account for one quarter of global trade (UNCTAD, 2015). In many cases, the export shares of commodities produced by natural resource industries have grown faster than those of typical manufactured products, such as pharmaceuticals and computers (World Trade Organization, 2010). Firms in natural resource industries are relevant market players (one in ten firms in Forbes' ranking of the largest public companies operates in mining, upstream oil, or forestry) and are also active non-market actors, topping the list for political campaign contributions. ${ }^{1}$ Finally, several developed and emerging economies are highly dependent on natural resource sectors (Venables, 2016). The historical development of Australia, Canada, Norway, and, to a large extent, even the United States originates from productivity gains in agriculture, mining, and oil. Today, countries like Azerbaijan, Brazil, Chile, and many African nations rely on natural resources to finance their (cyclical) growth and development programs (Deaton, 1999).

The importance of these industries notwithstanding, strategic management research has paid little, if any, attention to the particularities of natural resource industries and the challenges to survival and growth that they face (George, Schillebeeckx, \& Liak, 2015; Shapiro, Hobdabi, \& Oh, 2018). Although natural resources have long been examined through the lens of sustainability and environmental management (Hart, 1995; Sharma \& Vredenburg, 1998), these industries' competitive dynamics and the resulting firm-level performance implications remain largely understudied. This is both unexpected and difficult to explain. We argue that a more focused research emphasis on natural resource industries

\footnotetext{
${ }^{1}$ See Center for Responsive Politics: https://www.opensecrets.org/lobby/top.php?indexType=c\&showYear=2017
} 
would not only enhance the ability of strategy research to inform critical current debates, but also uncover novel and understudied issues that represent unique opportunities for theory refinement and development. Our objective is therefore to stimulate scholarly debate around issues faced by firms competing in natural resource sectors, capitalizing on their distinctive traits and eliciting critical implications for their competitive dynamics as well as their market and non-market strategies.

Our paper seeks to draw attention to the fact that, far from being 'mature' or 'stable' sectors, natural resource industries are fundamentally dynamic, exhibiting high turnover rates and substantial variation in within-sector competitive patterns across countries. ${ }^{2}$ We submit that a more detailed examination of these patterns can greatly inform potential new avenues of strategy research. At a more conceptual level, we ground our discussion in research that examines industry evolution as a process of resource accumulation and change (Cimoli, Dosi, Nelson, \& Stiglitz, 2009; Lazzarini, 2015; Teece, Pisano, \& Shen, 1997). Our contribution is to outline six general observations about relevant and often neglected features of natural resource industries influencing processes of value creation and appropriation, and then derive implications for future advances in strategy research.

Specifically, we observe that natural resource commodities are inherently standardized products that do not necessarily fit product lifecycle theories and, relatedly, that commodityproducing natural resource industries are not subject to frequent waves of radical product innovation but rather to process innovations. We also show that, unlike products in other sectors, natural resource commodities trade in both financial and physical markets, with

\footnotetext{
${ }^{2}$ We are aware of very few studies using good comprehensive data that allow for inter-industry comparisons of firm dynamics (e.g., Bartelsman et al., 2009; Buddelmeyer et al., 2006). However, such comparisons remain inherently difficult due to the scarcity of comprehensive, multi-sector, selection bias-free, micro-level panel data. Lack of data, however, should not obscure the relevance of strategic decision-making and the consequent firm dynamics in less studied industries.
} 
important implications for how firms develop competitive advantages in these multiple competitive arenas. In our view, these observations convey patterns of firm-level resource accumulation and change that are particularly relevant in natural resource industries. We also observe that in commodity sectors based on natural resources, cooperative rent-preserving mechanisms tend to be prevalent, largely defying competition policy, and that stakeholder engagement has a large influence on the appropriation of rents. Finally, we note that natural resource sectors are deeply intertwined with industrial development policies that can affect processes of both value creation and capture. Our view is that these last three observations relate to critical non-market forces that are highly prevalent in natural resource industries.

Building on these observations, we then discuss research implications for the study of firm strategy in natural resource industries. Our goal is to provide a systematic analysis of the theoretical challenges and research opportunities in the forgotten competitive arena of natural resource industries, and stimulate novel research advancing our understanding of industry and firm competitive behavior under the set of conditions that are uniquely present in those industries. All six observations above bring opportunities for both theoretical and empirical research. From a theoretical standpoint, we outline potential research avenues that, at their core, concern how firms in natural resource industries dynamically develop new or reinforced heterogeneous resources aimed at either value creation or capture. From an empirical standpoint, we delineate how singular features of natural resource industries can serve to empirically uncover the existence of otherwise hard to observe firm resources.

The rest of our paper consists of four sections. First, we document our methodical review of the relevant literature and explicitly provide evidence of the lack of strategy research focused on natural resource industries. Next, we elaborate our observations on the fundamental characteristics of natural resource industries as they pertain to strategy research. 
We build on these observations to propose paths for future research. The last section concludes.

\section{Research on Natural Resource Industries}

Research on strategic management in natural resource industries is scarce. To the best of our knowledge, George et al. (2015) was the first study to point out this void in the strategic management literature. Their review of publications in the Academy of Management Journal (AMJ) since its inception exposes a striking lack of attention to natural resource industries and firms operating in these markets. Their analysis reveals that the strategic management literature has confined the notion of resources to individual, organizational, and inter-organizational assets — as inspired by resource-based theory — and that, when mentioned, natural resources are rarely the focal aspect of a study, but rather seen as incidental to the management theory being addressed. ${ }^{3}$ Shapiro et al. (2018) confirm George et al.'s (2015) findings. Their review of original research published in four leading international business journals reveals that fewer than one percent of articles are focused on extractive and natural resource sectors.

Our own review of the literature expands George et al.'s (2015) analysis to four other leading management journals: Administrative Science Quarterly, Management Science, Organization Science, and Strategic Management Journal. We reviewed all issues published between 2006 and 2017. We first specified a definition for natural resource industries, taking as a starting point goods classified as natural resources in the United Nations System of

\footnotetext{
${ }^{3}$ These authors detect an almost complete absence of articles addressing the particularities of natural resource industries. Of the 3,456 AMJ articles published between 1963 and 2015, they find only 319 that have the term 'resource' in the title, abstract, author-supplied keywords, or subject terms. Of those 319 articles, only one specifies 'natural resources' as a keyword.
} 
National Accounts. ${ }^{4}$ According to this convention, natural resource commodities build on non-manufactured, naturally occurring assets (i.e., assets not created by an artificial production process). These consist of uncultivated forests and fish stocks, land, and mineral deposits. Natural resource commodities may be extracted and sold with minor processing, but they may also undergo more extensive secondary or downstream processing. While it is not always straightforward to draw the line between extractive and manufactured products made from natural resource inputs, natural resource commodities that undergo secondary processing may still be considered natural resources (IMF, 2017). Thus, our focus comprises firms involved in activities sorted under Division Structures A (agriculture, forestry, fishing) and B (mining and quarrying) in the International Standard Industry Classification (ISIC). ${ }^{5}$

Consistent with this categorization, natural resource industries share a common characteristic: they explore, develop or extract a host of natural resources (such as land for agricultural products or mineral reserves for metals) and, even if there is some transformation process involved, the natural resource represents a relevant portion of costs or physical extraction processes, and the resulting product remains a standardized asset traded in more or less fungible markets. ${ }^{6}$ This last feature justifies the common usage of the term 'natural resource

\footnotetext{
${ }^{4}$ International Standard Industrial Classification (ISIC), Revision 4, 2008. The database is freely available for download through the World Bank trade website (www.worldbank.orgltrade) under the Data \& Statistics section.

${ }^{5}$ These ISIC codes include agricultural production crops (01), agriculture production, livestock, and animal specialties (02), agriculture services (07), forestry (08), fishing, hunting, and trapping (09), metal mining (10), coal mining (12), oil and gas extraction (13) and mining and quarrying of nonmetallic minerals (14).

${ }^{6}$ Note that the products defined above trade on well-defined commodity exchanges such as the London Metal Exchange (LME) and the Chicago Mercantile Exchange (CME). Participants in the LME can trade up to 14 nonferrous (aluminum, copper, zinc, nickel, lead, tin), ferrous (steel scrap and steel rebar), minor (cobalt and molybdenum), and precious metals (gold, silver, palladium, platinum). The CME trades agriculture, energy, and metal commodities. Agriculture commodities include dairy, livestock, grains and oilseeds, lumber and pulp, and
} 
commodities' to describe products directly originated from natural resources, which is conceptually different from the case of manufactured products that become commoditized over time.

Our search procedure began with the identification of keywords and terms that would most typically denote academic research in natural resources. We determined these terms using George et al.'s (2015) query string and the identification of the commodity-producing industries depicted above. We then combined the identified terms and keywords into a search string that we operationalized in the Scopus database by restricting our query to papers in the five chosen journals that contain any of the string terms in their titles, abstracts, or authorsupplied keywords. ${ }^{7}$ The operationalization of the string yielded 138 articles. $^{8}$

We then examined the resulting papers in a three-stage process. Firstly, we carefully scrutinized the titles, keywords, and abstracts of all 138 articles in order to understand each one's treatment of natural resources and identify those that were actually about natural resource industries. Of this initial list, only 68 manuscripts related directly to natural resource

softs (such as coffee, cotton, and cocoa). The energy commodities are biofuels, coal, crude oil, natural gas, and petrochemicals, while the traded metals are mostly the same as those traded on the LME.

${ }^{7}$ The resulting search string is as follows: "natural resources*" OR wind OR oil OR gas OR solar OR steel OR forest OR diamond* OR gold OR silver OR coal OR ferrous OR aluminium OR copper OR dairy OR livestock OR grains OR oilseeds OR lumber OR pulp OR coffee OR cotton OR cocoa OR biofuels OR “natural gas" OR petroleum OR petrochemicals OR metal OR land OR agriculture* OR commodit* OR energy* OR renewable OR "natural environment".

${ }^{8}$ We first ran George et al.'s (2015) query string but noted that the search yielded several papers unrelated to natural resources due to the alternative meanings of the search terms "nature OR input OR material OR throughput OR water OR food". Therefore, we deleted those terms from our string and added several others based on our definition of natural resource industries: for example, George et al.'s (2015) string omits the search term 'gold' and thus does not capture Henisz et al.'s (2014) paper, but ours does. 
industries. ${ }^{9}$ Secondly, we agreed on a set of criteria to assess to what extent each paper's contribution is rooted in the particularities of commodities and natural resource industries. Based on these criteria, each of us screened every paper and judged whether it advances strategic management research. We found that most studies simply use natural resource industries as an empirical context, with no interest in drawing particular implications for firm behavior and/or outcome heterogeneity in those industries. Overall, we identified only eleven articles that seem to address, either theoretically or empirically, novel issues that specifically pertain to natural resource industries.

Our final list includes six papers on operations management (Boyabatl1, 2015; Chen, Tomlin, \& Wang, 2013; Dong, Kouvelis, \& Wu, 2014; Goel \& Gutierrez, 2011; Nadarajah, Margot, \& Secomandi, 2015; Wu \& Chen, 2010). None of these papers mentions the term 'strategy'; rather, they essentially focus on production optimization criteria and process design when strategic decisions have already been made (e.g., production capacity or product choice). One exception is Chen et al. (2013), who analyze product line design and process innovation in the case of products that can have multiple types of quality classification or grade.

In our review, we also identified two manuscripts addressing price volatility in natural resource industries (Popescu and Seshadri; 2013; Singleton, 2013). Both manuscripts point towards the fact that the existence of multiple markets increases the need for superior price monitoring and contracting capabilities. Weigelt and Shittu (2016) rely on the renewable industry to show that resource redeployment is not simply the outcome of internal firm decisions but a response to external regulatory mandates. Finally, Henisz, Dorobantu, and

\footnotetext{
${ }^{9}$ The search yielded several papers that use query terms in ways unrelated to natural resources. In several cases, the term 'commodity' is used to refer to a non-differentiated product with no connection to natural resources. In other cases, terms are used as metaphors.
} 
Nartey (2014) provide evidence that stakeholder engagement pays off by showing how investments in political and social capital in gold mining reduce opportunistic hold-ups by stakeholders with whom firms have no explicit buyer or supplier contracts but whose cooperation is nevertheless required to create and capture value. In a related study, they examine when and how social and political stakeholders mobilize against mining firms, and the impact of such mobilization on the firms' value (Dorobantu, Henisz, \& Nartey, 2017). Overall, our review reinforces George et al.'s (2015) initial findings.

\section{Strategy in Natural Resource Industries: Relevant Market and Non-Market Forces}

Why has the strategy literature overlooked the phenomenon and mechanisms explaining firm strategy in natural resource industries? One possibility is that management scholars implicitly or explicitly assume that natural resource industries lack economic relevance or sufficient competitive dynamism to deserve any focused research effort. However, we observe that, far from being 'mature' or 'stable' sectors, natural resource industries exhibit high rates of entry and exit and competitive patterns that are not necessarily different from what we observe in other industries (Bartelsman et al., 2009; Buddelmeyer et al., 2006). Yet, a set of idiosyncratic features that are singular to natural resources makes us conclude that we are looking at a unique and fertile research area for strategy research. We submit that a more focused examination of those industries could help identify the boundary conditions of existing theories and pursue novel advances.

To develop our argument, we consider that industry evolution typically involves a process of resource accumulation and change, subject to external shocks that alter the value of firms' resources and their relative positions in the industry (Cimoli et al., 2009; Teece et al., 1997). Departing from this general idea, we adopt a general framework, depicted in Figure 1, characterizing the evolution of natural resource industries as a process involving distinct paths of resource accumulation and change subject to market and technological uncertainty, as well 
as to institutional factors influencing the ability of firms to capture economic value (see, for example, Lazzarini, 2015). This general framework is not intended to explain uniquely how natural resource industries behave, as other sectors are equally subject to those processes of resource accumulation and change; rather, we use this framework to explain more didactically our underlying resource-based mechanisms and then outline specific dynamics whose more detailed examination can push the boundaries of existing strategy research.

*** Insert Figure 1 about here $* * *$

Our starting point is that firms in natural resource industries have various forms of resources at multiple levels of aggregation. Thus, departing from an existing resource endowment, firms can reinforce their existing specialization (paths 1 and 2). This might occur, for instance, when an agriculture-intensive country further expands its production and marketing capabilities. This process, however, is subject to resource depletion (path 3), given the non-renewable nature of some natural resources or the possibility that renewable natural resources may be exploited at an unsustainable rate. Alternatively, firms can pursue new development by building on natural resources (path 4). For instance, agricultural commodities might stimulate investment in other industrialized products with derived demand (such as dairy products, ethanol, or farm machinery), or an agricultural firm may transform itself into a financial trader with new, distinct market capabilities.

These (heterogeneous) paths are affected by important market and technological shocks that drastically change the value of natural resources and affect firms' incentives to pursue reinforced specialization or new specialization paths building from those natural resources. They are also influenced by the industrial policies in place, which essentially alter the incentives of agents to pursue particular paths of resource accumulation and change (Lazzarini, 2015). These policies can be general (country-level) or sector-specific (industrylevel); for instance, a given country may set general standards to deal with resource depletion 
or implement regulations and subsidies to promote alternative, sustainable technological processes. As a response to those regulations, firms may also geographically diversify their sourcing of natural resources, with operations that span distinct regions and even countries. In addition, strategy scholars have forcefully argued that the existence of valuable resources does not necessarily translate into superior industry- or firm-level economic performance, as stakeholders may have distinct bargaining power to negotiate and influence the distribution of rents (e.g., Coff, 1999; Garcia-Castro \& Aguilera, 2015). As we explain below, arrangements affecting rent appropriation can occur at the industry level (e.g., firms colluding to attenuate their rivalry and coordinate joint production) or network level (e.g., firms forming associations to manage mutual interdependencies and deal with multiple stakeholders). These rent-preserving arrangements can also influence the very process of policymaking (e.g., trade associations may lobby for particularly industry-specific policies), thereby leading to a bidirectional relationship between industrial policy and natural resources: while policies can affect processes of resource accumulation and change, the outcome of those processes can also influence policymaking through the political action of associations and various forms of stakeholder relations.

Using this general framework, the rest of this section presents our view on the idiosyncrasies of natural resource industries in the form of six general observations, which explain fundamental market and non-market forces influencing industry-, network-, and firmlevel strategies in those sectors.

\section{Observation \#1: The evolution of natural resource commodities is likely to follow different pathways than those described in product lifecycle theories}

The propositions of product lifecycle theories, which have been developed in a context of product differentiation, encounter substantial challenges when applied to natural resource commodities. At its core, the product lifecycle of differentiated products (Klepper, 1997) 
starts with a radical innovation that then triggers an imitation process - "an endogenous and dynamic two-way relationship between the variety (the range introduced) and selection (the relative importance of competing alternatives) of innovations" (Agarwal et al., 2002, p. 972). Initially, many firms enter the market, producing different variants of the product or service, and competition focuses on product innovation (Abernathy \& Utterback, 1978). Such innovations widen the competitive landscape as new entrants enlarge the industry base until technological and consumer uncertainties vanish and industry output takes off (Echambadi, Bayus, \& Agarwal, 2008). A bigger market attracts new entrants, increased rivalry pushes prices downward (Klepper \& Graddy, 1990), and firms refocus on cost efficiency. Subsequently, selection pressures emerge and determine both minimum scale survival thresholds (Muller, 1997) and competitive isolating mechanisms. This process finally results in the emergence of niche competitors and the exit of some firms (Agarwal et al., 2002; Klepper \& Graddy, 1990).

However, firms that compete in natural resource industries generally produce and trade commodities, ${ }^{10}$ which are assets whose economic value is based on highly standardized intrinsic characteristics that are usually independent of the producer. Commodities like soybeans or oil are totally or partially fungible, meaning that the market will trade them as long as they meet a specified minimum standard known as basis grade. For example, the market offers a spot price for all soybeans with a certain amount of protein, without reference to the farmer that produced them; similarly, the spot price for an ounce of $14 \mathrm{k}$ gold does not depend on the mining company that extracted it. Therefore, opportunities for product innovation are limited and prices tend to follow cyclical trends dictated by a complex

\footnotetext{
${ }^{10}$ There are some exceptions, however. For instance, in the case of rare earths, markets are less liquid and transactions are more dependent on specific negotiations. However, for the large majority of natural resource industries, our assessments apply..
} 
interplay of market and technological shocks. We argue that these features pose substantial challenges to the direct application of product lifecycle theories, which have been largely developed in a context of product differentiation.

It is true that, as indicated by path 4 in Figure 1, natural resource commodities can generate new forms of resource accumulation based on derived demand that occurs downstream (e.g., industrialized agricultural production) or somewhat inelastic supply upstream (e.g., mining equipment). For instance, McDermott, Corredoira, and Kruse (2009) describe a process of technological upgrading from agricultural to premium wine production in Argentina. However, these related industries display competitive dynamics that are fundamentally different from those of the natural resources that triggered the new resource accumulation in the first place. It is also true that, in some cases, commodity producers have tried to differentiate their products by emphasizing environmentally friendly processes, regional origin, or socially responsible practices (e.g., fair trade products), but the impact of these efforts has proved modest (see Delmas, Russo, \& Montes-Sancho, 2007). Thus, resource accumulation within natural resource industries tends to follow paths 1 and 2: over time, firms specialize their tangible assets and intangible capabilities to deliver standardized products that rarely change.

This restricted scope for product differentiation poses challenges for the direct application of extant product lifecycle theories. In natural resources, innovations are largely based on processes (see Observation \#2 below) rather than on product attributes - gas, iron, and wheat, for instance, have existed for centuries with their key attributes virtually unchanged. If the intrinsic features of a commodity are largely invariant, except perhaps for infra-marginal changes in grade, then we might expect particular competitive implications that, to some extent, should differ from those of differentiated products. Hence, we believe 
that existing product lifecycle theories would at best be incomplete in explaining dynamics in natural resource industries.

Along these lines, the long-term decline in prices for most manufactured products, which is a fundamental evolutionary pattern for differentiated product industries subject to increasing entry and imitation, does not necessarily hold for natural resource industries. Instead, the prices of natural resources oscillate in shorter cycles and longer waves or 'supercycles' (Erten \& Ocampo, 2012; Jacks, 2013), during which prices tend to exhibit high volatility (World Trade Report, 2010). Figure 2, for instance, compares the evolution of the inflation-adjusted US Producer Price Index for wood pulp to the US Consumer Price Index for new cars. The former series is much more volatile, featuring cycles that indicate unique and complex market dynamics. Figures $3 \mathrm{~A}$ and $3 \mathrm{~B}$, in turn, compare a group of commodities to other manufactured goods. In contrast to manufactured goods, prices have actually escalated in some commodity markets over time.

The explanation for this trend involves a combination of supply and demand factors that change over time. For instance, the accelerated economic growth of China and other emerging markets during the first decade of the twenty-first century increased the demand for commodities, whose supply is relatively inelastic, subject to unpredictable climate shocks, and affected by technological developments that help increase productivity. These myriad shocks most probably affect firm-level decisions to focus their resources on commodity production, even if the nature and attributes of their products remain unchanged. In short, natural resource sectors call for a much more refined theorizing of the aggregate and firmlevel forces that influence resource accumulation, beyond what is predicted by traditional product lifecycle theories.

*** Insert Figures 2, 3A, and 3B about here*** 


\section{Observation \#2: Natural resource industries are not subject to frequent waves of radical innovation, but rather to process innovation}

Since the intrinsic properties of commodity products hardly change, innovations in natural resource industries are mostly driven by changes in production processes. That is, the industry lifecycle sequence of product innovations followed by process innovations does not hold in these industries; instead, innovations mainly relate to production and organizational processes (Malerba \& Orsenigo, 1994). These gains further increase productivity, reducing cost and improving performance at a decreasing rate. When innovations are mostly processbased and aimed at increasing the productivity of existing resources, they tend to support reinforced specialization (paths 1 and 2 in Figure 1): over time, commodity producers become more productive, thus incentivizing more firm-specific investment to exploit their increased competitive advantage. In addition, the lower incidence of waves of radical product innovation limits the emergence of new competitors with new business models or distinctive capabilities. ${ }^{11}$

We generally observe that most industry innovations originate from firms that directly compete in a particular market. However, although natural resource producers often pursue continuous process improvements, a significant amount of process innovation also emanates from suppliers. ${ }^{12}$ For example, increased productivity in agriculture resulted from technological improvements in the farm sector (such as no-till farming), but also benefitted from innovation waves pursued by producers of farm inputs. Monsanto, for example, triggered important improvements in farming through biotechnology (i.e., chemical-resistant

\footnotetext{
${ }^{11}$ It is worth noting that, since process innovation increases production potential, it may have an adverse impact on the market, since the additional supply may alter the existing supply-demand equilibrium, pushing prices downward. In fact, it could happen that in the short term, this effect might be similar to that observed in other industries, during the development and mature stage of the industry life cycle (Klepper, 1997).

${ }^{12}$ Relatedly, Pavitt (1984) shows that in capital intensive industries, innovation is mostly generated by providers.
} 
soybeans), which represents a technological change emanating from an upstream sector influencing the process of resource accumulation in the core, focal natural resource industry (agricultural production). It is also possible that these innovations may result from close interactions with users, which should also encourage and promote subsequent refinements (Oliveira \& von Hippel, 2011). These forces affect the process of technology diffusion and adoption in those industries.

The fact that process innovation in natural resource industries is in several cases not only endogenous but also exogenous (e.g., coming from distinct related sectors) implies that copying what others are doing is simpler: the best available technologies will spread faster than in industries in which at least some reverse engineering of competitor inventions is required. When technology diffusion is faster, achieving first mover advantage through process innovation becomes more difficult, or the size of the advantage remains smaller. Since innovations are potentially exogenous to downstream industry dynamics, suppliertriggered process innovations in commodity industries generate important movements in downstream competition, increasing productivity and altering the mechanisms of value creation and value appropriation.

\section{Observation \#3: The volume of commodity exchange-traded financial derivatives is much larger than physical production}

Natural resource commodities are more or less fungible assets that can be traded in both physical and financial markets. Consequently, a large number of commodity exchanges around the world trade different commodities and commodity-derived financial contracts (e.g., futures and options contracts) at a market-arbitrated price, regardless of the identity of the producers. For example, forest products such as lumber and pulp, as well as agricultural products such as wheat, corn, soybeans, oats, and livestock, trade on the Chicago Board of Trade (CME), while ferrous metals like aluminum, copper, and gold are traded on the London Metal Exchange 
(LME). In practice, this fact implies that a typical commodity trades several times in 'parallel' markets before reaching the physical market. Different sources report that the volume of commodities traded under financial contracts is much larger than their physical production, and that this ratio has grown substantially during the twenty-first century (Domanski \& Heath, 2007; Silvennoinen \& Thorp, 2013; UNCTAD, 2012). For gold, copper, and aluminum, the volume of exchange-traded derivatives was around 30 times larger than their physical production in 2005.

Moreover, the emergence of these derivative markets has resulted in increased market volatility (Duffie \& Jackson, 1989; Silvennoinen \& Thorp, 2013). Financial investors, who accounted for less than 25 percent of all commodity market participants in the 1990s, represented more than 85 percent of participants in 2010 (UNCTAD, 2012). Because there are many more financial investors, the value of price hedging and speculation strategies now tends to increase when demand and supply conditions are highly uncertain. The increase of commodity-backed financial markets results from two relevant attributes of natural resource industries, discussed before: the tendency toward reinforced specialization (creating large markets of undifferentiated products) and the presence of recurring industry shocks, which creates derived demand for financial mechanisms to deal with and profit from market uncertainty. In addition, in contrast to most markets where consumer preferences reveal that the current value of goods exceeds their future value (e.g., manufactured goods subject to competing and improved innovations launched over time), ${ }^{13}$ firms in commodity markets must critically examine demand and supply forces that may create upward price trends.

These complex features require distinct capabilities for firms to compete in each arena. For instance, some firms can develop a competitive advantage in the physical market for soybeans (e.g., competencies in origination and logistics), as in path 1 in Figure 1, whereas other firms can develop new specialized resources and capabilities to operate in financial

\footnotetext{
${ }^{13}$ Vaccines and art might be exemptions.
} 
markets anchored on commodities (e.g., in arbitrage pricing and hedging), as in path 4 in Figure 1. Moreover, some firms may vertically integrate both activities and even dynamically diversify their portfolio of capabilities. For example, Bunge Born, a multinational, was originally conceived as a grain producer but later exited production and became an important financial trader in commodities. In other words, the path of reinforced specialization may involve improved capabilities not only in physical commodity markets but also in complex financial markets anchored on commodities.

\section{Observation \#4: In commodity sectors based on natural resources, cooperative rent- preserving mechanisms tend to prevail}

Conventional wisdom states that commodity prices are purely speculative and highly unpredictable, and that structural features in supply and demand make commodities the textbook example of perfectly competitive markets. Yet a closer look at the supply side and the institutional features of commodity markets — both national and international — reveals that oligopolistic forces are fully at play and that producers of natural resources capture value through cooperative rent-preserving arrangements. Hence, alternative forms of (explicit or tacit) collusion are phenomena that, perhaps paradoxically, can be more prevalent in commodity sectors due to the standardized nature of the product (which facilitates the creation of common market signals) and the high concentration in commodity sectors subject to substantial economies of scale (Motta, 2003). Even when production is more atomized, large organizations responsible for the commercialization of commodities may help enforce price and quantity coordination (e.g., Ghemawat \& Lenk, 1990; The Economist, 2010). Cooperation can also arise as a mechanism for countervailing supplier and customer power, given the high concentration in sectors with upstream or downstream linkages to natural resource industries. In other words, competitors in natural resource industries likely exhibit a 
coopetition pattern whereby they compete but at the same time create multiple non-market cooperative arrangements to preserve rents (Gnyawali \& Madhavan, 2006; Lavie, 2007).

For instance, while domestic producers at the sub-national level are most frequently numerous and undifferentiated, exporting institutions and international agreements often create a virtual global oligopoly of several nations (OPEC is an archetypal example). ${ }^{14}$ Empirical evidence documents explicit or tacit collusion arrangements in cocoa, coffee, rubber, sugar, and tin (Genesove \& Mullin, 1998; Gilbert, 1996; Igami, 2015); basic metals such as aluminum, copper, lead, nickel, tin, and zinc (Slade \& Thille, 2006); and scarce mining products such as diamonds, gold, silver, and uranium (Spar, 1994). While these cases of collusion often occur at the industry level, cooperation may also occur at the network level — that is, firms may form voluntary groups or associations to manage their joint production and marketing efforts. Thus, arrangements such as cooperatives, federations, and associations tend to implement alternative forms of output restriction practice to ensure returns and price stability: see Bolotova (2016) for evidence on US dairy and potato markets and Steen and Salvanes (1999) on the Norwegian salmon industry.

\section{Observation \#5: In commodity markets associated with geographically specific natural resources, stakeholder engagement has a large influence on the appropriation of rents}

The exploitation of natural resources also creates unique challenges in terms of managing stakeholder relations and interacting with multiple public and private actors directly or indirectly affected by firm-level strategies (Baker, Gibbons, \& Murphy, 2002; Baron, 2001; Shaffer, 1995). Unlike other production processes that do not heavily rely on land, water, or mineral reserves as key inputs, firms in commodity industries must demonstrate that

\footnotetext{
${ }^{14}$ In this case, explicit (as opposed to tacit) collusion may be particularly relevant, especially when many producers are involved-i.e., price and quantity coordination may require the presence of a formal agency representing the interests of multiple actors.
} 
they are not overexploiting natural resources and that the rents generated from their activities are benefiting, or at least not harming, relevant stakeholders. Physically extracted natural resources may also be closely linked with community-level history, territory, wealth, and the anthropological value of land (Hale, 2006). Research on stakeholder identification and salience suggests that the exploitation of these local resource endowments may be perceived as illegitimate (Mitchell, Agle, \& Wood, 1997), especially when these activities are run by firms that do not share the social identity of those local groups, as is often the case with foreign entrants (Jensen, 1994). It is no surprise, then, that the particular features of natural resource markets force firms to face challenges from activists in the domain of private politics (Henisz et al., 2014). In some cases, rents from natural resources may fund and even trigger armed conflict (Le Billon, 2001). Essentially, the influence of multiple stakeholders constrains firms' ability to appropriate value from natural resources, making the management of complex stakeholder networks essential to increasing the legitimacy of local operations (Lamin \& Zaheer, 2012).

At the same time, perceived market power and potential negative externalities in natural resource industries trigger the revision of international trade agreements, the passing of domestic laws and regulations, and the involvement of competition authorities. In other words, stakeholder relations may also affect the bargaining power of industry actors and change their ability to appropriate value from their existing resources (Coff, 1999). In addition, stakeholder relations can influence the design of industrial policies. It is well established that interest groups can impact individual political decision-makers and policy outcomes (De Gorter \& Swinnen, 2002); and political decision-makers, for their part, can shape commodity-related public policies to fulfill their personal goals or ideologies (Bellemare \& Carnes, 2015; Klomp \& de Hann, 2013; Park \& Jensen, 2007). All these types of stakeholder relations can help industry actors manage the risks inherent in the exploitation 
of natural resources. Although the environmental and sustainability implications of natural resources have been extensively studied, we still know relatively little about the complex interactions that emerge as multiple stakeholders try to appropriate positive value or avoid negative impacts from natural resource industries.

\section{Observation \#6: Commodity sectors based on natural resources tend to have a large influence on industrial development policies}

Our sixth and final observation concerns the role of government policymaking: that is, we examine the importance of industrial development policies, defined as government interventions aimed at promoting paths of resource accumulation that would normally occur in free markets (Cimoli et al., 2009; Lazzarini, 2015). As mentioned before and explained in Figure 1, commodity sectors based on natural resources tend to be heavily intertwined with industrial development policies. Consider first how policy can affect resource accumulation and change. In the context of natural resources, this effect is exemplified in the debate of the so-called 'resource curse'. Resource-rich developing countries tend to grow by exporting basic commodities, drawing heavily on natural resources rather than on more 'advanced' differentiated, technology-intensive products. This process arguably causes overspecialization in tradable commodities and may induce negative spillovers into other sectors. For instance, exporting natural resource commodities strengthens a country's currency and makes industrialized products less competitive in global markets (for a review, see Frankel, 2010). In this setting, some argue that policymakers should deliberately try to incentivize alternative paths of resource accumulation and act as a countervailing force against the natural tendency of resource-rich countries to specialize in commodities (e.g., Amsden, 2001).

On the other hand, recent work has shown that, under some conditions, the resource curse can become a resource blessing: productivity gains in commodity sectors can release resources (such as labor and financial resources) to fuel the development of other sectors (see, 
for example, Bustos, Caprettini, \& Ponticelli, 2016). In addition, as mentioned above, when commodity producers face massive positive demand shocks, other domestic industries may benefit from increased derived demand for services or other industrialized products. In some cases, governments may actively stimulate the development of new industries with rents derived from natural resources (e.g., path 4 in Figure 1). For instance, the Chilean government has taxed copper producers to support programs to stimulate technological entrepreneurship (Lazzarini, 2015).

However, the outcomes of resource accumulation can also influence the design of policies via the political action of industry associations, politically connected networks, or stakeholders more generally (Haber \& Menaldo, 2011). Being regulated and subject to changes in government policy, natural resource sectors are often the targets of politicians trying to secure compensation for favors and changes in regulation implemented to benefit certain firms and constituencies. At the same time, firms may develop strategies to adapt and even influence policy (Shaffer, 1995). For instance, many countries concentrate the production and extraction of natural resources in 'national champions' supported and even owned by the state. Pressure from incumbent producers of commodities may also induce governments to support natural resource industries more than other industries; in other words, political action can also fuel the cycle of reinforced resource specialization (paths 1 and 2 in Figure 1).

Thus, the reverse causal effect, where the outcomes of resource accumulation affect industrial policies, is essentially influenced by cooperative and stakeholder-based arrangements that try to preserve and appropriate rents. This point is particularly relevant in the case of commodities subject to frequent (and unpredictable) market shocks, which generate rents that need to be redistributed among players. For instance, Ramírez and Tarziján (forthcoming) show that an increase in the price of minerals increases the extent of value 
appropriation by employees, and that this effect is moderated by government policies and regulations. They find that value capture by employees (in the form of higher wages) increases in the case of employees of state-owned enterprises, which tend to be prevalent in natural resource sectors. This finding suggests that government involvement with national champions not only affects firm-level performance but also influences the behavior and outcomes of diverse stakeholders trying to appropriate gains from valuable resources (Coff, 1999).

As this example suggests, the interplay between stakeholders and industrial policies may be particularly relevant and direct in the case of state-owned enterprises. They may also encompass a hybrid combination of state and private owners with diverging interests, which should induce not only critical principal-agent conflicts, but also principal-principal conflicts - i.e., misalignment between multiple shareholders (Dharwadkar, George, \& Brandes, 2000). For instance, state owners may mandate higher royalties from the extraction of oil and mining resources, which may reduce profits and hence reduce the ability of private owners to extract value from their equity investments (Musacchio \& Lazzarini, 2014). ${ }^{15}$

\section{Implications and Suggestions for Future Research}

We now build on the six observations above to discuss research implications for the study of firm strategy in natural resource industries. Table 1 summarizes our research suggestions, linking each proposal to the observations described above. In our view, there is considerable room for substantial and novel investigations into the determinants of competitive advantage, non-market value capture mechanisms, and public policy outcomes based on dynamics occurring in commodity markets. More specifically, drawing on the

\footnotetext{
${ }^{15}$ Industrial policies can also be shaped by way of influence and pressure activities exerted by organized networks such as civic, government support institutions, and transnational-wide interest groups (e.g., farmer interest groups with an EU-wide membership — so called Euro groups), which, for instance, enjoy an exclusive position in the formation of agricultural policy within the EU political process (van der Zee, 1997).
} 
distinctive features of natural resource industries outlined above, we suggest potential research opportunities to generate new insights or refine basic theoretical tenets in strategic management.

\section{*** Insert Table 1 about here ***}

\section{Beyond the Product Lifecycle}

In our observation $\# 1$, we argued that natural resource industries involve products that are more or less stable in their physical attributes, rendering the application of traditional product lifecycle theories less pertinent than in differentiated product industries. This observation calls for more research on how firms' product strategy evolves beyond the usual dynamics of new product introduction or the replacement of obsolete designs. Future research can examine alternative forms of differentiation involving progressive changes in nonphysical attributes or increased product variety within the bounds of standardized patterns. These changes may also involve innovations in production processes (observation \#2). For instance, agribusiness chains have adopted traceability mechanisms to identify the origin of (a priori homogenous) products and certification procedures to verify attributes or process requirements (e.g., sustainable agricultural production). This research agenda can draw from early studies on measurement-based theories of the firm (e.g., Barzel, 1982; Delmas et al., 2007; Poppo \& Zenger, 2002) and potentially generate new theoretical propositions on the creation and evolution of capabilities to measure, shape, and enforce commodities' attributes.

In addition, since commodities' product lifecycle is largely static, the main concept and competitive mechanisms behind the industry lifecycle, as it applies to natural resources, should be revisited on at least two grounds. Firstly, the presence of intangible assets in manufacturing and technological industries (e.g., brand or product R\&D) usually explains the formation of cohorts of large firms with higher survival rates and, eventually, the advent of successful niche competitors. Yet, when intangible assets are absent, size advantages play a 
reduced role, allowing mid-size competitors to enjoy higher survival rates (Cruz Novoa, Reyes, \& Vassolo, 2016). Secondly, the need for cost competition in the context of undifferentiated products might limit the viability of niche strategies. All in all, natural resources offer an opportunity to revise strategy theories explaining industry evolution, firmlevel rents, and survival rates.

Closely tied to this argument is the quest for the optimal level of within-industry diversification, which we define as the process of increasing product variety in the same industry through the creation of submarkets (Zahavi \& Lavie, 2013). Resource partitioning scholars focus on the existence or creation of different submarkets within an industry to explain survival. According to this view, organizations evolve to become specialists or generalists (Freeman \& Hannan, 1983; Singh \& Lumsden, 1990). Specialists offer a narrow set of products, seeking to take advantage of efficiency gains and targeting particular customer types (Barroso \& Giarratana, 2013). Generalists, in contrast, draw on a broad range of resources and serve a broad range of customers. These underlying theories anticipate a U-shaped relationship between within-industry diversification levels and firm survival and performance. However, in the absence of an underlying product lifecycle, and with lower possibilities of building competitive advantage through intangible assets, the mechanisms explaining these relationships should also be revisited. One suggestion would be to revisit the direct relationships between scale economies at the product level and scope economies at the firm level on the one hand, and performance and survival on the other. We are particularly calling for longitudinal empirical studies in this area.

Natural resource industries are providers of basic inputs to industries that are subject to the product lifecycle. Therefore, although it is inappropriate to directly apply product lifecycle theory to commodities, commodity industries are not totally independent of the competitive dynamics of industries subject to the lifecycle. For example, the increase in the 
demand for lithium resulting from the emergence of the electric car industry has bolstered lithium prices. Eventually, when this industry reaches maturity, or finds a substitute for lithium, lithium prices will fall. However, this does not necessarily imply that competitive evolution in natural resource industries will mimic that of industries based on non-commodity products, particularly because the versatility of natural resources eventually allows them to be applied to alternative, non-related uses. Examining such interactions between the product lifecycle and demand-side factors may be a promising agenda for future research.

\section{Recurring Entry Timing Advantages}

The industry dynamics literature explores the potential competitive advantages enjoyed by firms when the timing of entry precedes or follows that of competitors (Echambadi, Bayus, \& Agarwal 2008; Zachary et al., 2015). In industries subject to waves of radical product innovation, pioneers (very early entrants) risk losing competitive advantage due to product underdevelopment or a lack of consumer demand for the new product (Min, Kalwani, \& Robinson 2006). Moreover, while industry standards are still in flux, pioneers might become trapped in a product design that customers do not want (Min et al., 2006).

Also, as discussed in our observation \#2, technology disruptions are scarce and mainly related to production processes. Despite these characteristics, which would seem to diminish entry timing advantages, entry and exit timing decisions are fundamental for differential performance in natural resource industries. These decisions are particularly important due to the potentially negative correlations between the prices of alternative products that can be produced using a scarce natural resource. For example, the owner of a vineyard must decide whether to produce grapes for red or white wine. She has full knowledge of current prices but cannot anticipate future prices, since they depend on the entry decisions of other competitors. The decision to switch markets has an implicit time lag — and therefore an opportunity cost- 
until the new product reaches full production (e.g., grapevines must grow for several years before grapes can be harvested).

This opens an important avenue of research related to theories of entry timing advantages. This research agenda includes opportunities to apply game theory reasoning. For example, if a minority of firms enters one market while most competitors remain in the other market, the minority group may have the opportunity to earn higher revenues as prices rise in the former, non-crowded market. While the minority game has been widely used in other contexts (Challet \& Zhang, 1998), natural resource industries appear to be an attractive setting for theoretical extension examining boundary conditions influencing entry timing advantages.

In addition, the high temporal volatility in the prices of the same natural resource product (as per our observation \#1) reinforces the value of inter-temporal arbitrage, transforming it into a fundamental capability for firms competing in natural resource industries. Hence, the evolution of prices in natural resource markets makes transaction timing different from that observed in other industries. For instance, in the case of manufactured, differentiated goods, firms have to deal with specific temporal patterns (e.g., launching a new product in a holiday season) and often face a downward price trend due to the launch of competing product varieties. In natural resource commodities, in contrast, prices critically vary within and across years, and may even escalate over time due to temporal scarcity, changing the way producers define the timing of their optimal selling and entry strategies.

Finally, given that (as per our observation \#6) national champions tend to be relevant in natural resource industries, the presence of state-sponsored firms can also transform entry timing advantages. For instance, some firms may receive disproportionate state support; this extra capital may help fund their growth strategies in domestic or international markets (Falck, Gollier, \& Woessmann, 2011; Musacchio \& Lazzarini, 2014). Holding all else equal, 
lower entry costs (as a function of heavy subsidies and support) will stimulate firms to pursue early entry and preemptive strategies to outcompete higher-cost competitors solely with private capital. In a context involving multiple national champions, entry timing advantages may also depend on the willingness and ability of their sponsoring governments to support their expansion and cope with intense ex-post competition.

\section{Renewed Emphasis on Process-Based Innovation and Capabilities}

Although scholars have long discussed the differences between product- and processbased innovations, a more careful examination of innovation patterns in natural resource industries can spark renewed theoretical and empirical interest in the latter (as emphasized in our observation \#2). We foresee several opportunities for theory elaboration by considering processes that occur interdependently in long value chains, as is typical for natural resource commodities. For instance, the competitive advantage of an exporting mining firm requires not only superior capabilities in mineral extraction, but also domestic processing and transportation (e.g., railroads), shipping overseas, and delivery in foreign countries (e.g., Khanna, Musacchio, \& Pinho, 2010). Even if mining firms do not innovate in terms of product attributes, they can progressively promote substantial interdependent innovation in all of these sequential stages. Firms may also develop unique, heterogeneous strategies to own and manage multiple links in the value chain (e.g., Hsieh, Lazzarini, \& Nickerson, 2010). Although such vertical integration decisions are also common in other industries, natural resource commodities traded in large markets provide an ideal context for studying how process innovations emerge and evolve in long, sequential value chains, usually spanning several countries.

The analysis of long, complex value chains also raises several research questions regarding how the partners of natural resource firms operate and evolve. Connecting with our observation \#4, which emphasizes the role of cooperation and coopetition in natural resource 
industries, future research can also examine how these relationships change in a context where radical innovations are rare. The literature on coopetition has examined how the value of partners changes with surges of new technologies that disrupt existing business models (Afuah, 2000). In natural resources, it is possible that partnerships are relatively more stable, with suppliers progressively accumulating capabilities via learning-by-doing processes. However, as mentioned above, natural resources may be subject to upstream or downstream technological shocks. Producers of agricultural or mining inputs, for instance, may implement important innovations that change the productivity of commodity sectors and alter their competitive position vis-à-vis their rivals. Market shocks may also be relevant: even if baseline technologies do not change, commodity firms may frequently switch suppliers (e.g., farmers may change their fertilizer or seed suppliers as a function of their relative prices) or alter the supply schedule as a function of cyclical changes in demand (e.g., a grain-processing firm may sever ties with smaller cooperatives if there is a substantial drop in client orders).

Furthermore, an emphasis on process-based capabilities can inform a more recent trend in strategy research: examining heterogeneous practices in addition to heterogeneous resources. Bromiley and Rau (2014), for instance, argue that strategy scholars should pay more attention to routines and organizational activities, even if they are well-known and potentially imitable. A complex interplay between firm-level resources, industry forces, and contextual factors can greatly influence whether firms will be able to understand the value of certain practices and implement performance-enhancing processes. For instance, although certain agricultural process-based technologies are well known and widely available, the adoption of these practices depends on farm-level resource endowments (such as infrastructure or human capital), as well as contextual conditions (such as linkages with farm input companies offering technology transfer programs). Heterogeneous process improvement 
can be a way to generate firm-specific competitive advantage even in highly competitive markets.

\section{Capability to Deal with Multiple Markets anchored on the same Commodity}

We argued in our observation \#3 that commodities have multiple linked markets, including markets for financial derivatives that are usually much more liquid and volatile than their physical counterparts. This setting creates a unique opportunity to study firm-level capabilities to manage multiple markets anchored on the same product. For instance, the strategic reorientation of Vitol and Glencore illustrates the challenges that firms face when transitioning from middlemen to vertically integrated operators. ${ }^{16}$ On the one hand, distinct activity systems and processes may force firms to specialize in managing either financial or physical markets; on the other hand, firms may be able to leverage their knowledge of physical markets to develop and support trading strategies in financial markets, or vice versa.

Potential synergies between physical and financial derivative markets are particularly important if we consider volatility as an important dimension of performance in strategic management. Derivative markets usually involve future price quotes and mechanisms to hedge against undesirable price variation. In fact, there is a broad array of organizational forms available to firms to manage volatility. A steel company, for instance, can vertically integrate backwards in the mining sector, use future or option contracts traded on commodity exchanges, or develop customized contracts with suppliers that define future delivery prices (e.g., Almeida, Hankins, \& Williams, 2017). These capabilities will also be a manifestation of process innovations that firms develop over time (as per observation \#2) - in this case, innovations related to the ability to deal with multiple markets and contracts. Natural resource industries, again, provide an ideal setting to study strategies for managing temporal price

\footnotetext{
${ }^{16}$ For anecdotal accounts, see "Commodities traders face growing pains", Financial Times, 26 April 2012.
} 
linkages and the complex interplay between multiple markets anchored on the same commodity.

\section{Institutional and Non-Market Forces affecting Value Creation and Appropriation}

Our framework identifies processes that influence rent generation from natural resources as well as mechanisms that allow industries, networks, and firms to appropriate differential economic value. In our observation \#4, we stressed that the homogeneous nature of natural resource commodities facilitates intra-industry price and quantity coordination led by large firms and powerful industry organizations. ${ }^{17}$ In economics, most studies focus on aggregate, industry-level effects of collusion (Motta, 2003); much less attention has been devoted to how firms appropriate heterogeneous benefits from these cooperative arrangements. Along these lines, and using natural resource industries as an empirical context, a fruitful research agenda would be to examine how cooperative arrangements evolve as a function of industry- and network-level interactions, and how these interactions influence the ability of firms to appropriate differential value, above and beyond what their coopetitors can attain.

The idiosyncratic features of natural resource industries also create several opportunities to explore value appropriation in the context of multiple stakeholders, as suggested in our observation \#5. Exploiting value chains anchored on key, scarce natural resources poses key challenges for managing stakeholder relations. We discussed earlier how perceptions of excessive value captured by one particular party (e.g., multinational firms exploiting natural resources in a foreign country) can trigger backlash and conflict in the presence of exogenous supply and demand shocks or under the risk of relevant resource

\footnotetext{
${ }^{17}$ Which is not the norm in other industries; see Ozer and Lee (2009). As we noted before, even when production markets are atomized, large organizations may be responsible for the commercialization of products and hence implement commitment mechanisms to enforce prices and quantities (see, for example, Ghemawat \& Lenk, 1990).
} 
depletion. While Henisz et al. (2014) show how investments in political and social capital reduce opportunistic hold-ups by stakeholders, they do not examine how instrumental stakeholder engagement varies in the presence of endogenous competition (e.g., depletion) or exogenous shocks.

Further research on the potential rents generated by natural resource industries can help advance ongoing theoretical discussions on value creation and appropriation in a more complex, multi-stakeholder setting (Garcia-Castro \& Aguilera, 2015; Klein, Mahoney, McGahan, \& Pitelis, forthcoming). A particularly interesting feature of natural resource industries discussed above is that they are subject to market and technological shocks that hold the potential to influence value creation and redistribution. For instance, although some agricultural biotechnology innovations increased farm-level efficiency and productivity, they triggered a debate on how to share these gains among suppliers and farms. Sudden variations in the price of commodities also create an opportunity to examine how multiple stakeholders negotiate and redistribute their gains.

\section{Strategy and Industrial Development Policy}

Scholarly interest in the policy implications of firm-level strategies has increased over time (Barney, 2005; Mahoney, McGahan, \& Pitelis, 2009). Natural resource industries present unique opportunities to examine the complex interplay between policymaking and competitive strategizing. As mentioned in our discussion of observation \#6, there is a bidirectional association between the design of industrial policies and the evolution of natural resource industries. On the one hand, industrial policies can change the path of resource accumulation and change, a phenomenon that has been understudied in strategy (Lazzarini, 2015). Thus, policies can help promote investment in technologies oriented toward countrylevel development and/or riskier R\&D efforts in which the private sector has no interest. For instance, Thurber and Istad (2010) argue that state involvement in the Norwegian oil industry 
stimulated the development of novel technologies in deep water exploration. In addition, the fact that natural resources have more or less stable and undifferentiated traits (observation \#1) opens a discussion of whether governments should promote upgrading and diversification of potential outputs coming from commodity sectors. A fruitful research agenda involves exploring how government policies can change the paths of reinforced specialization (paths 1 and 2 in Figure 1) or, alternatively, stimulate the development of new resources and capabilities derived from natural resources (path 4).

Moreover, because valuable natural resources are generally not only rare but also subject to depletion, it would be worthwhile to study the comparative effects of governmentinduced versus voluntary firm-level strategies to regulate excessive exploitation of natural resources, as well as transition mechanisms to more renewable sources. As mentioned before, firms may also be incentivized to diversify their geographical sourcing of scarce natural resources and even develop strategies to deal with multiple, rare products. One particular case is that of commodity byproducts of mining activity (i.e., metals that result from the mining of other major industrial metals; Talens Peiro, Mendez, \& Ayres, 2011). This list includes gallium (from bauxite); arsenic, cobalt, molybdenum, rhenium, selenium, and tellurium (from copper ore); cadmium, germanium, and indium (from zinc); cobalt (from nickel); and rhodium and ruthenium (from platinum and palladium). A particular challenge of these metals is that the increase in demand stemming from the rapid development of certain final product technologies, particularly because of their availability, can limit the lifetime of such technologies (Talens Peiro, Mendez, \& Ayres, 2013). Therefore, addressing these challenges might require active public policies.

On the other hand, industries, cooperative networks, and organizational stakeholders more generally can critically influence the design of policies. Because natural resource commodities such as oil or minerals are often seen as strategic, most governments choose to 
manage these resources via national champions in the form of state-owned enterprises or private firms with relevant government influence. Yet the very presence of the government in these sectors creates the possibility of dysfunctional political interference. Governments may try to appropriate economic or political benefits by directly or indirectly controlling these organizations; and, in response, national champions - and their various stakeholders - may develop myriad strategies to bargain with governments and preserve their rents. Because natural resource industries are subject to constant market and technological shocks that can drastically alter the value of commodities, examining the market and non-market mechanisms that influence the redistribution of gains or losses can be a rewarding research agenda (see, as an example, Ramírez \& Tarziján, forthcoming).

\section{Conclusion}

Natural resource industries represent a significant proportion of economic activity in both emerging and developed markets. Despite this fact, strategic management research on natural resource industries remains scarce in, if not totally absent from, the main journals in the field. This lack of attention may bank on the implicit assumption that strategic insights from other industries are directly transferable to the specific context of commodity industries. While the dynamics of natural resource industries may seem similar to those of other, more intensively researched sectors, we highlight that the forces behind such dynamics differ in several key dimensions from what is observed in manufacturing, services, or technological industries.

Our paper highlights several key differences between natural resource industries and other sectors. For instance, we have drawn attention to the fact that commodities are inherently standardized products that do not necessarily fit oft-quoted product lifecycle theories. Such standardization results in two particularly unique traits. One is the fact that natural resource industries are largely characterized by process rather than product 
innovation; the other is that the normalized features of commodities facilitate their trading in financial markets at levels well above those in physical markets. Moreover, the extent of both the physical and the financial trading of commodities leads to the oft-used textbook example of perfectly competitive commodity markets. No less important, firm-level performance in commodity markets is largely affected by non-market institutional arrangements, which, in turn, can have non-trivial redistribution consequences. These features, we argue, provide a rich opportunity to expand theories examining the role of complex stakeholder interactions and developing policies - forces that can critically influence the ability of firms to create and appropriate value from natural resources.

Our work highlights these differences and provides potential research avenues to address unexplored but consequential theoretical and empirical gaps. In our view, pursuing such research will enrich our understanding of idiosyncratic industry- and firm-level determinants of heterogeneous firm performance in natural resource industries. In addition, studying strategy in natural resource industries has important implications for teaching in the management field. Since theoretical models inform the conceptual approaches taught in universities, the lack of research on natural resource industries may lead to the use of inappropriate or, at best, incomplete analytical frameworks, limiting the utility of strategic management classes for students who later pursue careers in natural resource industries. We believe that our suggested research agenda may not only improve the understanding of how natural resource industries function, but also benefit strategic management as a whole through the examination of the structural conditions, institutional factors, and competitive mechanisms involved in these industries.

\section{REFERENCES}

Abernathy, W. J., \& Utterback, J. M. (1978). Patterns of Industrial Innovation. Technology Review, 80(7): 4047. 
Afuah, A. (2000). How much do your "co-opetitors"” capabilities matter in the face of technological change? Strategic Management Journal, 21: 387-404.

Agarwal, R., Sarkar, M., \& Echambadi, R. (2002). The Conditioning Effect of Time on Firm Survival : an Industry Life Cycle Approach. Academy of Management Journal, 45(5): 971-994

Almeida, H., Hankins, K. W., \& Williams, R. (2017). Risk management with supply contracts. The Review of Financial Studies, 30(12), 4179-4215.

Amsden, A. H. (2001) The rise of "the rest": challenges to the west from late-industrializing economies. Oxford: Oxford University Press.

Baker G, Gibbons R, Murphy K. J. (2002). Relational contracts and the theory of the firm. Quarterly Journal of Economics, 117(1): 39-84.

Barney, J. B. (2005). Should strategic management research engage public policy debates?. Academy of Management Journal, 48(6), 945-948.

Baron D. P. (2001). Private politics, corporate social respon- sibility, and integrated strategy. Journal of Economics \& Management Strategy, 10(1): 7-45.

Barroso, A., \& Giarratana, M. S. (2013). Product proliferation strategies and firm performance: The moderating role of product space complexity. Strategic Management Journal, 34(12), 1435-1452.

Bartelsman, E., Haltiwanger, J., \& Scarpetta, S. (2009). Measuring and analyzing cross-country differences in firm dynamics. In Producer dynamics: New evidence from micro data (pp. 15-76). University of Chicago Press.

Barzel, Y. (1982). Measurement costs and the organization of markets. Journal of Law and Economics, 25: 2748.

Bellemare, M. F., \& Carnes, N. (2015). Why do members of congress support agricultural protection?. Food Policy, 50, 20-34.

Bhaskarabhatla, A., \& Klepper, S. (2014). Latent submarket dynamics and industry evolution: lessons from the US laser industry. Industrial and Corporate Change, 23(6), 1381-1415.

Bolotova, Y. V. (2016). Agricultural Supply Management and Market Power: Evidence from the US Dairy and Potato Industries. Agribusiness, 32(4), 563-568.

Boyabatl1, O. (2015). Supply management in multiproduct firms with fixed proportions technology. Management Science, 61(12), 3013-3031. 
Bromiley, P., Rau, D. (2014). Towards a practice-based view of strategy. Strategic Management Journal, 35(8): 1249-1256.

Buddelmeyer, H., Jensen, P. H. \& Webster, E. (2006). Innovation and the determinants of firm survival. IZA DP No. 238

Bustos, P.; Caprettini, B. \& Ponticelli, J. (2016). Agricultural productivity and structural transformation: Evidence from Brazil. The American Economic Review, 106(6): 1320-1365.

Center for Responsive Politics: https://www.opensecrets.org/lobby/top.php?indexType=c\&showYear=2017

Challet, D., \& Zhang, Y. C. (1998). On the minority game: Analytical and numerical studies. Physica A: Statistical Mechanics and its Applications, 256(3-4), 514-532.

Chen, Y. J., Tomlin, B., \& Wang, Y. (2013). Coproduct technologies: Product line design and process innovation. Management Science, 59(12), 2772-2789.

Cimoli, M., Dosi, G.; Nelson, R., Stiglitz, J. E. (2009). Institutions and policies shaping industrial development: an introductory note. In Industrial Policy and Development: The Political Economy of Capabilities Accumulation, Cimoli M, Dosi G, Stiglitz JE (eds). Oxford University Press: Oxford, UK; 19-38.

Coff, R. W. (1999). When competitive advantage doesn't lead to performance: The resource-based view and stakeholder bargaining power. Organization science, 10(2), 119-133.

Cottrell, T., \& Nault, B. R. (2004). Product variety and firm survival in the microcomputer software industry. Strategic Management Journal, 25(10), 1005-1025.

Cruz Novoa, A., Reyes, T., \& Vassolo, R. (2016). Size Competition Revisited: The Advantages of Middle Size Competition in Commodity Industries. Academy of Management Proceedings, Vol. 2016, No. 1, p. 10204.

Deaton, A. (1999). Commodity prices and growth in Africa. The Journal of Economic Perspectives, 13.3: 2340 .

De Gorter, H. \& Swinnen, J. (2002). Political economy of agricultural policy. Handbook of Agricultural Economics, 36: 1893-1943.

Delmas, M., Russo, M. V., \& Montes-Sancho, M. J. (2007). Deregulation and environmental differentiation in the electric utility industry. Strategic Management Journal, 28(2), 189-209.

Dharwadkar, R., George, G., \& Brandes, P. (2000). Priatization in emerging economies: an agency theory perspective. Academy of Management Review, 25(3), 650-669.

Domanski, D., \& Heath, A. (2007). Financial investors and commodity markets. BIS Quarterly Review, March 2007. 
Dong, L., Kouvelis, P., \& Wu, X. (2014). The value of operational flexibility in the presence of input and output price uncertainties with oil refining applications. Management Science, 60(12), 2908-2926.

Dorobantu, S., Henisz, W. J., \& Nartey, L. (2017). Not all sparks light a fire: Stakeholder and shareholder reactions to critical events in contested markets. Administrative Science Quarterly, 62(3), 561-597.

Duffie, D., Jackson, M. O. (1989) Optimal innovation of futures contracts. The Review of Financial Studies, 2(3): 275-296.

Echambadi, R., Bayus, B. L., Agarwal, R. (2008). Entry timing and the survival of startup and incumbent firms in new industries. Working paper, University of Illinois, Champaign

Erten, B., \& Ocampo, J. (2012). Super-cycles and commodities prices since the mid-nineteenth century. United Nations Department of Economic and Social Affairs (DESA) Working Paper Series, vol. 110.

Falck O., Gollier C. \& Woessmann L. (2011). Arguments for and against policies to promote national champions. In Falck O, Gollier C, Woessmann L (eds.), Industrial policy for national champions. MIT Press: Cambridge.

Frankel J. (2010). The natural resource curse: a survey. Harvard Kennedy School Research Working Paper Series 10-005.

Freeman, J., \& Hannan, M. T. (1983). Niche width and the dynamics of organizational populations. American Journal of Sociology, 88(6), 1116-1145.

Garcia-Castro, R., \& Aguilera, R. V. (2015). Incremental value creation and appropriation in a world with multiple stakeholders. Strategic Management Journal, 36(1), 137-147.

Genesove, D., \& Mullin, W. P. (1998). Testing static oligopoly models: conduct and cost in the sugar industry, 1890-1914. The RAND Journal of Economics, 355-377.

George, G., Schillebeeckx, S. J., \& Liak, T. L. (2015). The management of natural resources: An overview and research agenda. Academy of Management Journal, 58(6), 1595-1613.

Ghemawat, P., \& Lenk, T. (1990). De Beers Consolidated Mines Ltd.(A). Harvard Business School Case.

Gilbert, C. L., (1996), International Commodity Agreements: An Obituary Notice. World Development, 24(1), pp. 1-19.

Gnyawali, D. R., He, J., Madhavan, R. (2006). Impact of co-opetition on firm competitive behavior: An empirical examination. Journal of Management, 32(4): 507-530.

Goel, A., \& Gutierrez, G. J. (2011). Multiechelon procurement and distribution policies for traded commodities. Management Science, 57(12), 2228-2244. 
Haber, S., and Menaldo, V. (2011). Do natural resources fuel authoritarianism? A reappraisal of the resource curse. American Political Science Review, 105: 1-26.

Hale, C. R. (2006). Activist research v. cultural critique: Indigenous land rights and the contradictions of politically engaged anthropology. Cultural anthropology, 21(1), 96-120.

Hart, S. L. (1995). A natural-resource-based view of the firm. Academy of Management Review, 20(4), 9861014.

Hashai, N. (2015). Within-industry diversification and firm performance - an S-shaped hypothesis. Strategic Management Journal, 36(9), 1378-1400.

Hee Park, J., \& Jensen, N. (2007). Electoral competition and agricultural support in OECD countries. American Journal of Political Science, 51(2), 314-329.

Henisz, W. J., Dorobantu, S., \& Nartey, L. J. (2014). Spinning gold: The financial returns to stakeholder engagement. Strategic Management Journal, 35(12), 1727-1748.

Hsieh, C., Lazzarini, S. G., Nickerson, J. A., \& Laurini, M. (2010). Does ownership affect the variability of the production process? Evidence from international courier services. Organization Science, 21(4), 892-912.

Igami, M. (2015). Market power in international commodity trade: The case of coffee. The Journal of Industrial Economics, 63(2), 225-248.

International Monetary Fund, (2017). Guide to Analyze Natural Resources in National Accounts. Available in www.imf.org/external/pubs/ft/qna/pdf/na.pdf

Jacks, D. S. (2013). From Boom to Bust: A Typology of Real Commodity Prices in the Long Run. NBER Working Paper Series. no. 18874.

Jensen, N. (2008). Political risk, democratic institutions, and foreign direct investment. The Journal of Politics, 20(4):1040-52.

Khanna, T., Musacchio, A., \& de Pinho, R. R. (2010). Vale: global expansion in the challenging world of mining. Papers.ssrn.com

Klein, P. G., Mahoney, J., McGahan, A. M., Pitelis, C. (Forthcoming). Organizational governance adaptation: Who is in, who is out, and who gets what. Academy of Management Review.

Klepper, S. (1997). Industry life cycles. Industrial and Corporate Change, 6(1), 145-182.

Klepper, S., \& Graddy, E. (1990). The Evolution of New Industries and the Determinants of Market Structure. The RAND Journal of Economics, 21(1): 27-44. 
Klepper, S., \& Thompson, P. (2006). Submarkets and the evolution of market structure. The RAND Journal of Economics, 37(4), 861-886.

Klomp, J., \& De Haan, J. (2013). Conditional election and partisan cycles in government support to the agricultural sector: An empirical analysis. American Journal of Agricultural Economics, 95(4), 793-818.

Lamin A, Zaheer, S. (2012). Wall Street vs. Main Street: Firm strategies for defending legitimacy and their impact on different stakeholders. Organization Science, 23(1): 47-66.

Lavie, D. (2007). Alliance portfolios and firm performance: a study of value creation and appropriation in the U.S. software industry. Strategic Management Journal, 28: 1187-1212.

Lavoie, N. (2005). Price discrimination in the context of vertical differentiation: an application to Canadian wheat exports. American Journal of Agricultural Economics, 87(4), 835-854.

Lazzarini, Sergio G. (2015). Strategizing by the government: Can industrial policy create firm-level competitive advantage? Strategic Management Journal, 36(1), 97-112.

Le Billon, P. (2001) The political ecology of war: natural resources and armed conflicts. Political Geography, 20: 561-584.

Mahoney, J. T., McGahan, A. M., Pitelis, C. N. (2009). The interdependence of private and public interests. Organization Science, 20(6): 1034-1052.

Malerba, F., \& Orsenigo, L. (1996). The dynamics and evolution of industries. Industrial and Corporate Change, 5(1), 51-87.

McDermott, G. A., Corredoira, R. A., Kruse, G. (2009) Public-private institutions as catalysts of upgrading in emerging market societies. Academy of Management Journal, 52: 1270-1296.

Mitchell, R. K., Agle, B. R., Wood, D. J. (1997). Toward a theory of stakeholder identification and salience: Defining the principle of who and what really counts. Academy of Management Review. 22(4), 853-86.

Min, S., Kalwani, M. U., \& Robinson, W. T. (2006). Market pioneer and early follower survival risks: A contingency analysis of really new versus incrementally new product-markets. Journal of Marketing, 70(1), 15-33.

Musacchio, A. \& Lazzarini, S. G. (2014). Reinventing State Capitalism: Leviathan in Business, Brazil and Beyond. Cambridge: Harvard University Press.

Nadarajah, S., Margot, F., \& Secomandi, N. (2015). Relaxations of approximate linear programs for the real option management of commodity storage. Management Science, 61(12), 3054-3076. 
Oliveira, P., von Hippel, E. (2011) Users as service innovators: The case of banking services. Research Policy, 40: 806-818.

Ozer, M., \& Lee, S. H. (2009). When do firms prefer individual action to collective action in the pursuit of corporate political strategy? A new perspective on industry concentration. Business and Politics, 11(1), 1-21.

Pavitt, (1984). Sectoral patterns of technical change: Towards a taxonomy and a theory. Research Policy, 13(6), 343-373.

outlook. JOM, The Journal of the Minerals, Metals and Material Society, 65(8), 986-996.

Popescu, D. G., \& Seshadri, S. (2013). Demand uncertainty and excess supply in commodity contracting. Management Science, 59(9), 2135-2152.

Poppo, L., Zenger, T. R. (2002). Do formal contracts and relational governance function as substitutes or complements? Strategic Management Journal, 23(8): 707-726.

Ramírez, C., Tarziján, J. (Forthcoming). Stakeholder value appropriation: the case of labor in the worldwide mining industry. Strategic Management Journal.

Shaffer, B. (1995). Firm-level responses to government regulation: Theoretical and research approaches. Journal of Management, 21(3), 495-514.

Shapiro, D., Hobdari, B., \& Oh, C. H. (2018). Natural resources, multinational enterprises and sustainable development. Journal of World Business, 53, 1-14

Sharma, S., \& Vredenburg, H. (1998). Proactive corporate environmental strategy and the development of competitively valuable organizational capabilities. Strategic Management Journal, 19(8), 729-753.

Silvennoinen, A., \& Thorp, S. (2013). Financialization, crisis and commodity correlation dynamics. Journal of International Financial Markets, Institutions and Money, 24, 42-65.

Singh, J. V., \& Lumsden, C. J. (1990). Theory and research in organizational ecology. Annual Review of Sociology, 16(1), 161-195.

Singleton, K. J. (2013). Investor flows and the 2008 boom/bust in oil prices. Management Science, 60(2), 300318.

Slade, M. E., \& Thille, H. (2006). Commodity Spot Prices: An Exploratory Assessment of Market Structure and Forward-Trading Effects. Economica, 73(290), 229-256.

Sorenson, O. (2000). Letting the market work for you: An evolutionary perspective on product strategy. Strategic Management Journal, 577-592.

Spar, D. L. (1994). The cooperative edge: The Internal politics of international cartels. Cornell University Press. 
Steen, F., \& Salvanes, K. G. (1999). Testing for market power using a dynamic oligopoly model. International Journal of Industrial Organization, 17(2), 147-177.

Stern, I., \& Henderson, A. D. (2004). Within-business diversification in technology-intensive industries. Strategic Management Journal, 25(5), 487-505.

Talens Peiro, L., Méndez, G. V., \& Ayres, R. U. (2011). Rare and critical metals as by-products and the implications for future supply. INSEAD Working Paper Series, 2011/129/TOM/ISIC.

Talens Peiró, L., Méndez, G. V., \& Ayres, R. U. (2013). Lithium: sources, production, uses, and recovery Tanriverdi, H., \& Lee, C. H. (2008). Within-industry diversification and firm performance in the presence of network externalities: Evidence from the software industry. Academy of Management Journal, 51(2), 381397.

Teece D. J., Pisano G. P., \& Shuen, A. (1997). Dynamic capabilities and strategic management. Strategic Management Journal, 18, 509-533.

The Economist (2010). Rare Earths. Digging in. September 2 ${ }^{\text {nd }}, 2010$

Thurber, M. C., \& Istad, B. T. (2010). Norway's evolving champion: Statoil and the politics of state enterprise. Program on Energy and Sustainable Development Working Paper, 92.

Timmer, M. P., de Vries, G. J., \& de Vries, K. (2015). "Patterns of Structural Change in Developing Countries." . In J. Weiss, \& M. Tribe (Eds.), Routledge Handbook of Industry and Development. (pp. 65-83). Routledge.

UNCTAD (2012). Don’t blame the physical markets. Policy Biref, No 25, September.

UNCTAD. (2015). World Tariff Profiles 2015. Geneva: WTO.

van der Zee, F. A. (1997). Political Economy Models and Agricultural Policy Formation: Empirical Applicability and Relevance for the CAP.Mansholt Studies 8, Wageningen Agricultural University.

Venables, A. J. (2016). Using natural resources for development: why has it proven so difficult? The Journal of Economic Perspectives, 30(1), 161-183.

Weigelt, C., \& Shittu, E. (2016). Competition, regulatory policy, and firms' resource investments: The case of renewable energy technologies. Academy of Management Journal, 59(2), 678-704.

World Trade Organization. (2010). World Trade Report, Trade in Natural Resources.

Wu, O. Q., \& Chen, H. (2010). Optimal control and equilibrium behavior of production-inventory systems. Management Science, 56(8), 1362-1379. 
Zachary, M. A., Gianiodis, P. T., Payne, G. T., \& Markman, G. D. (2015). Entry timing: Enduring lessons and future directions. Journal of Management, 41(5), 1388-1415.

Zahavi, T., \& Lavie, D. (2013). Intra-industry diversification and firm performance. Strategic Management Journal, 34(8), 978-998. 
FIGURE 1: FRAMEWORK FOR ANALYZING STRATEGY IN NATURAL RESOURCE INDUSTRIES

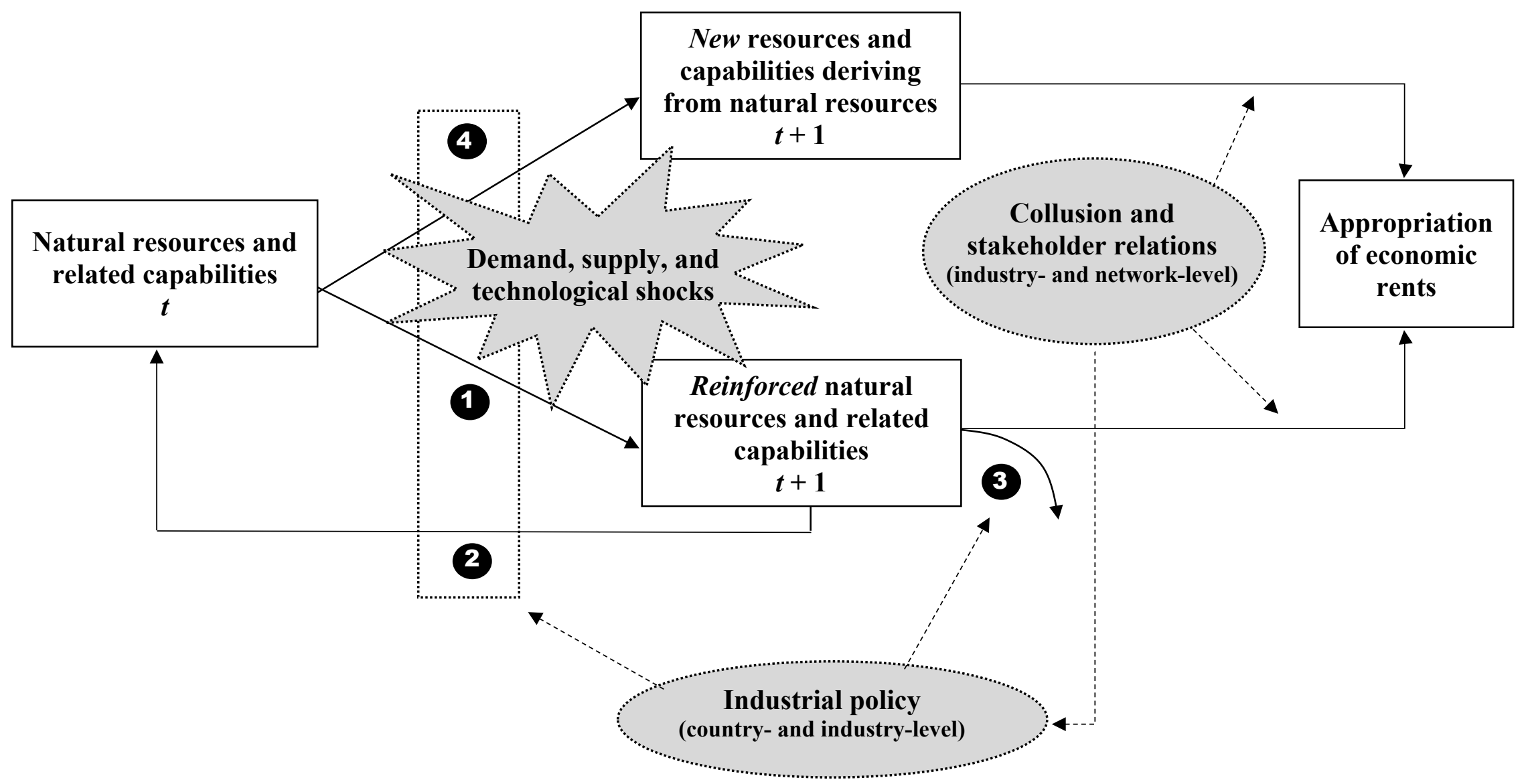

Legend: (1) = accumulation of specialized natural resources and capabilities; (2) = feedback loop via demand or supply factors; (3) = depletion of natural resources; (4) = creation of new resources and capabilities derived from natural resource sectors. 
FIGURE 2: INFLATION-ADJUSTED MONTHLY PRICE INDICES FOR WOOD PULP AND

\section{NEW CARS}

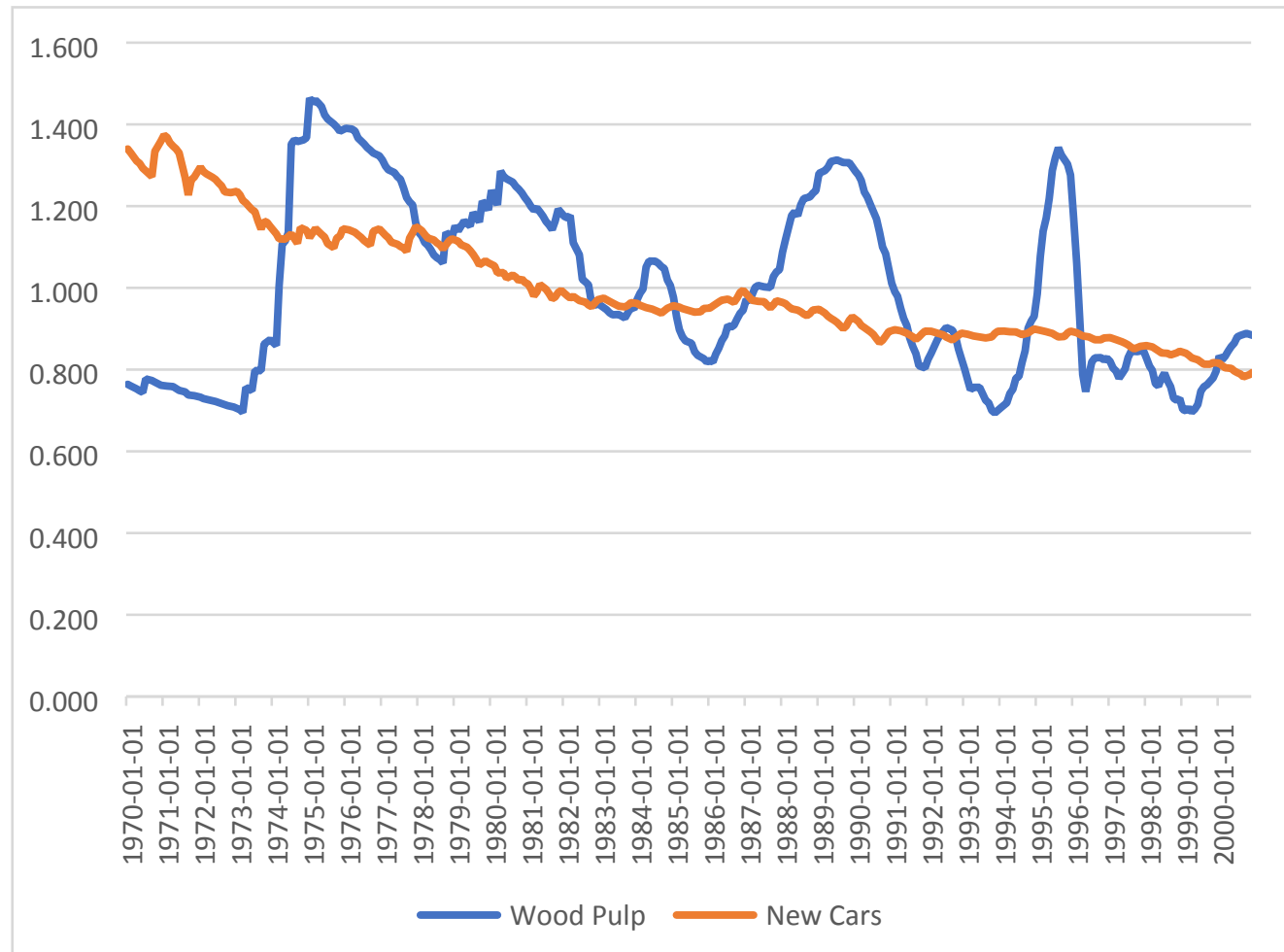

Source: Bureau of Labor Statistics. All series are in constant 1997 prices. 
FIGURE 3A: INFLATION-ADJUSTED YEARLY PRICE INDICES FOR TECHNOLOGICAL PRODUCTS

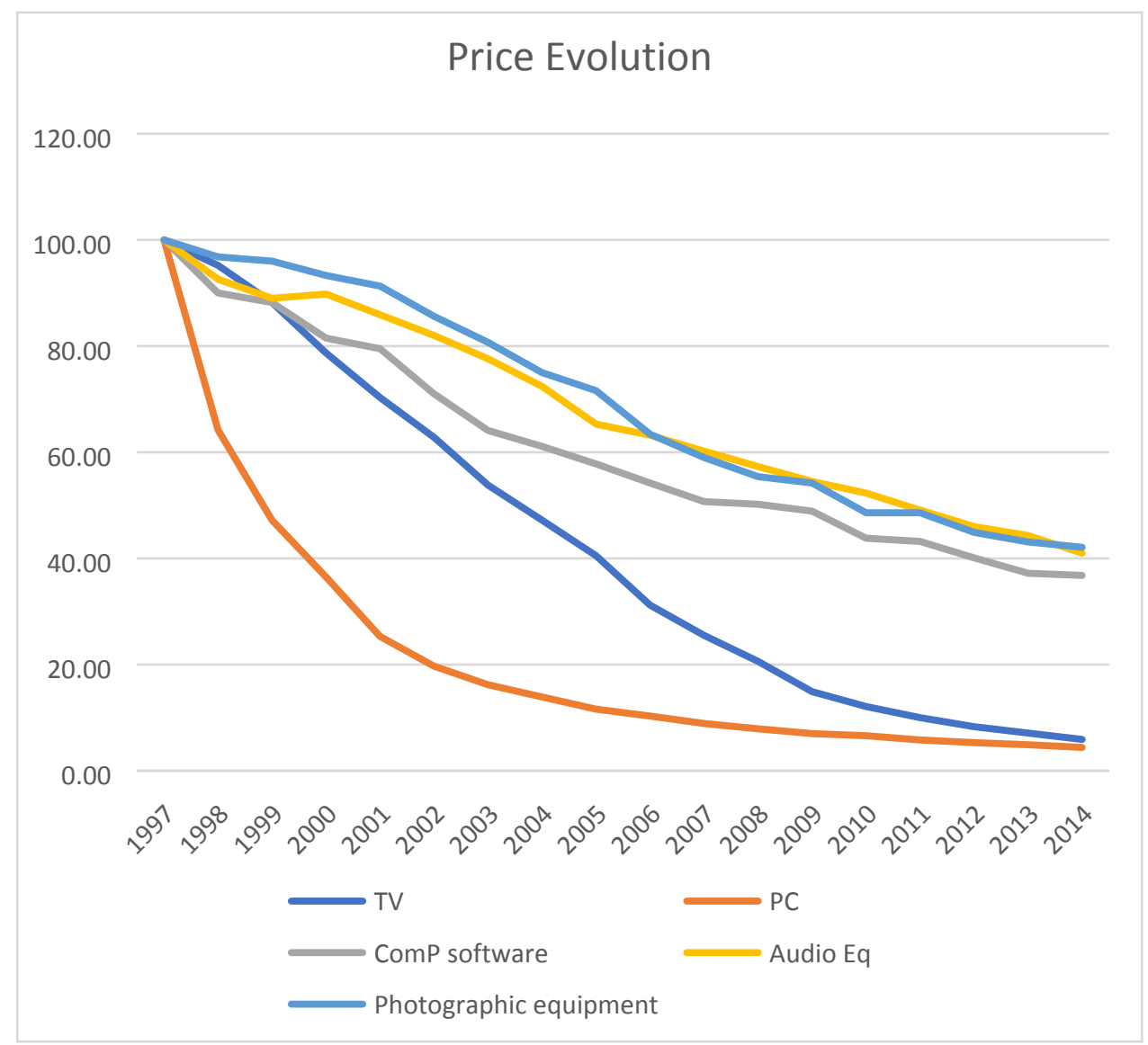

Source: Bureau of Labor Statistics. All series are in constant 1997 prices. 
FIGURE 3B: INFLATION-ADJUSTED YEARLY PRICE INDICES FOR COMMODITY PRODUCTS

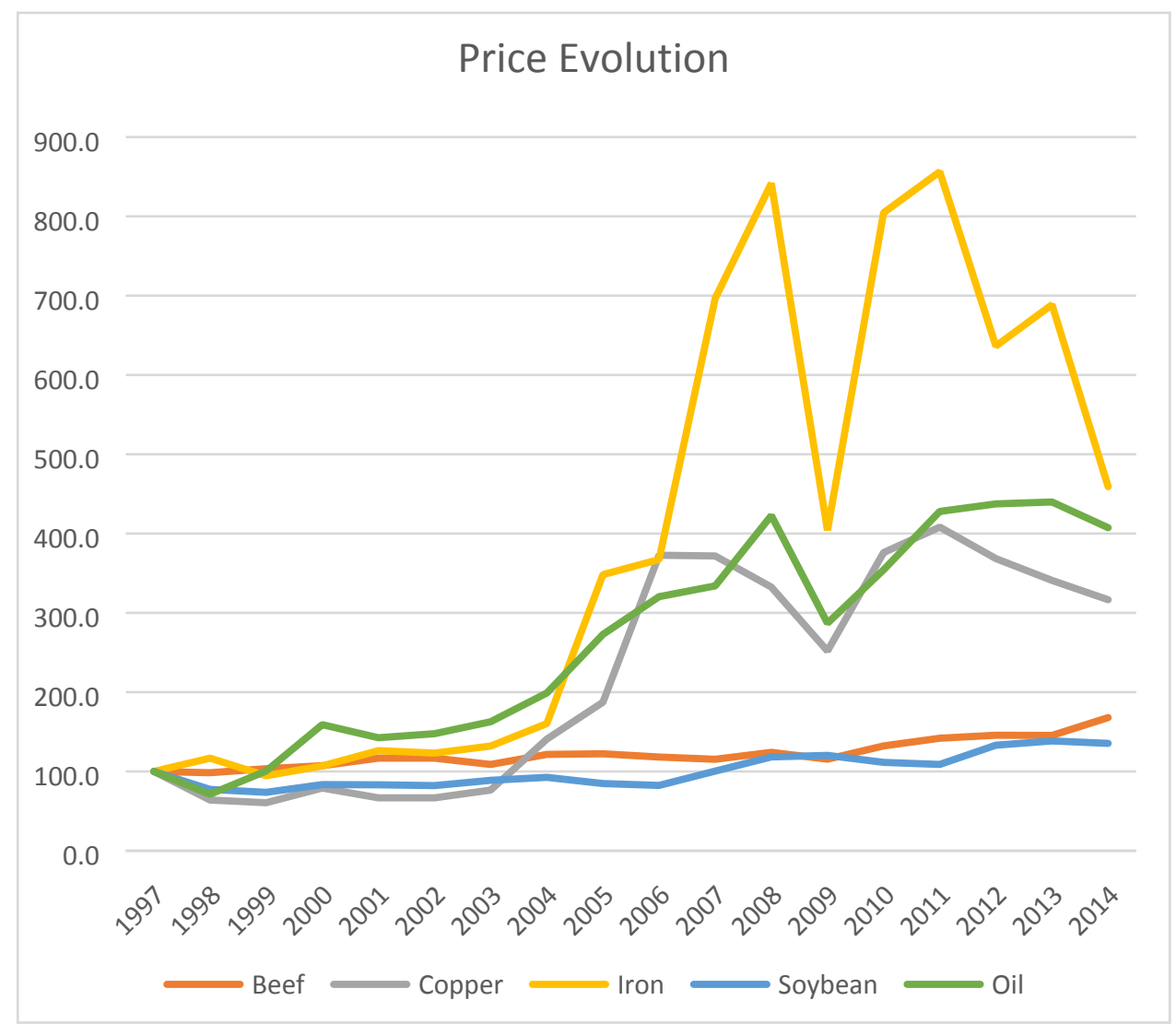

Source: Capital IQ. All series are in constant 1997 prices. 
TABLE 1. SUGGESTIONS FOR FUTURE RESEARCH DERIVED FROM KEY FEATURES OF NATURAL RESOURCE INDUSTRIES

\begin{tabular}{|c|c|}
\hline Potential research agenda & Link with key features of natural resources \\
\hline $\begin{array}{l}\text { Examining competitive dynamics } \\
\text { beyond the product lifecycle }\end{array}$ & $\begin{array}{l}\text { Natural resource industries involve products that are more or less } \\
\text { stable in their physical attributes, thereby rendering the application } \\
\text { of traditional product lifecycle theories less pertinent than in } \\
\text { differentiated product industries (observation \#1). In this context, } \\
\text { scholars should pay crucial attention to changes in production } \\
\text { processes rather than changes in the product per se (observation } \\
\# 2 \text { ). }\end{array}$ \\
\hline $\begin{array}{l}\text { In-depth analysis of recurring entry } \\
\text { timing advantages }\end{array}$ & $\begin{array}{l}\text { Because natural resources are usually commodities whose features } \\
\text { barely evolve over time (observation } \# 1 \text { ), and technology changes } \\
\text { are scarce and mainly related to production processes (observation } \\
\# 2 \text { ), these industries provide a unique setting for analyzing } \\
\text { recurring entry timing advantages. Additionally, entry decisions } \\
\text { may be affected by non-market factors, such as various types of } \\
\text { government incentive and support (observation } \# 6 \text { ). }\end{array}$ \\
\hline $\begin{array}{l}\text { Renewed emphasis on the study of } \\
\text { process-based innovation and } \\
\text { capabilities }\end{array}$ & $\begin{array}{l}\text { In natural resource industries, innovations are mostly based on the } \\
\text { development of improved processes (observation \#2). Furthermore, } \\
\text { given the importance of cooperation and coopetition in these } \\
\text { industries (observation \#4), distinct patterns of process-based } \\
\text { innovation may change the mechanisms through which partners can } \\
\text { create and appropriate value from new, improved processes and } \\
\text { practices. }\end{array}$ \\
\hline $\begin{array}{l}\text { Examination of complex capabilities to } \\
\text { deal with multiple markets anchored on }\end{array}$ & $\begin{array}{l}\text { Commodities have multiple linked markets, including markets for } \\
\text { financial derivatives that are usually much more liquid and volatile }\end{array}$ \\
\hline
\end{tabular}




\begin{tabular}{|c|c|}
\hline the same products & $\begin{array}{l}\text { than their physical counterparts (observation \#3). Thus, there is an } \\
\text { opportunity to study firm-level capabilities to manage multiple } \\
\text { markets anchored on the same product (e.g., the markets for } \\
\text { physical commodities and commodity derivatives). The evolution } \\
\text { of these capabilities likely involve constant change in market- } \\
\text { related processes (observation } \# 2 \text { ). }\end{array}$ \\
\hline $\begin{array}{l}\text { Scrutinizing the institutional and non- } \\
\text { market forces affecting value creation } \\
\text { and appropriation }\end{array}$ & $\begin{array}{l}\text { The homogeneous nature of natural resource commodities } \\
\text { facilitates intra-industry price and quantity coordination led by large } \\
\text { firms and powerful industry organizations (observation \#4). At the } \\
\text { same time, these firms and organizations need to deal with potential } \\
\text { conflict involving the distribution of economic value between } \\
\text { various stakeholders in natural resource-rich localities (observation } \\
\# 5 \text { ). }\end{array}$ \\
\hline $\begin{array}{l}\text { Strategy and industrial development } \\
\text { policy: the origin and development of } \\
\text { 'national champions' }\end{array}$ & $\begin{array}{l}\text { Industrial policies can have important consequences for the } \\
\text { accumulation and change of natural resources and capabilities. For } \\
\text { instance, because products based on natural resources have more or } \\
\text { less stable and undifferentiated traits (observation \#1), } \\
\text { policymakers often debate whether countries should promote } \\
\text { upgrading or diversification into other sectors, or instead stimulate } \\
\text { national champions involved in natural resource industries. In } \\
\text { another direction, industry players may try to preserve or } \\
\text { appropriate rents emanating from natural resources via their } \\
\text { influence on policymaking (observation \#6). }\end{array}$ \\
\hline
\end{tabular}




\section{Short bios}

Ariel A. Casarin (ariel.casarin@uai.cl) is an Associate Professor of Strategy at Adolfo Ibáñez Business School. He received his Ph.D. from the University of Warwick. His research concerns empirical industrial economics, nonmarket strategy and regulatory and competition policy issues in developing economies.

Sergio G. Lazzarini (sergiogl1@insper.edu.br) is the Chafi Haddad Professor of Management at Insper Institute of Education and Research. He received his Ph.D. from Washington University in St. Louis. He does research on how institutional conditions affect corporate strategy, the organization of the public-private interactions, and how private investors address social impact.

Roberto S. Vassolo (rvassolo@iae.edu.ar) is a Full Professor of Strategy at the IAE Business School, Argentina and a visiting professor at Pontificia Universidad Católica de Chile. He received his Ph.D. from Purdue University. He currently does research in competitive strategy in recessions, competition in natural resources industries and strategic leadership. 